\title{
Silver Diamine Fluoride
}

\author{
Gary Badger* \\ Department of Pediatric Dentistry, The University of Texas School of Dentistry, USA
}

Submission: December 19, 2017; Published: February 12, 2018

*Corresponding author: Gary Badger, Department of Pediatric Dentistry, The University of Texas School of Dentistry at Houston, USA, Tel: 713486 4142, Email: Gary.Badger@uth.tmc.edu

\section{Opinion}

Silver Diamine Fluoride (SDF) has changed the landscape for treating caries in children! With the acceptance of the drug by the FDA in 2014, many dental programs throughout the U.S. have begun using, researching, and applying this "silver" bullet to treat caries with as little disruption to the child as possible. When caries develops to such a degree that it results in occasional irritation to a preschooler, this new drug replaces the removal of carious dentin with the simple application of the drug with a micro brush. The occasional symptoms means that the carious process has not reached the nerve of the tooth and that intervention with 38\% ammoniacal silver fluoride will result in the arrest of the decay process and reinforce the enamel of affected teeth. The drop of SDF to the affected tooth allows the silver to react with the bacterial load causing a bactericidal effect. The results of the application cause remineralization of the affected dentin changing the color of the tooth to a dark brown to black stain. Fig. 1 The fluoride component of the liquid reinforces the enamel of the remaining tooth structure as a preventive effect. Of course, the solution is contraindicated for children with any allergy to the components of the solution. (Figure 1)

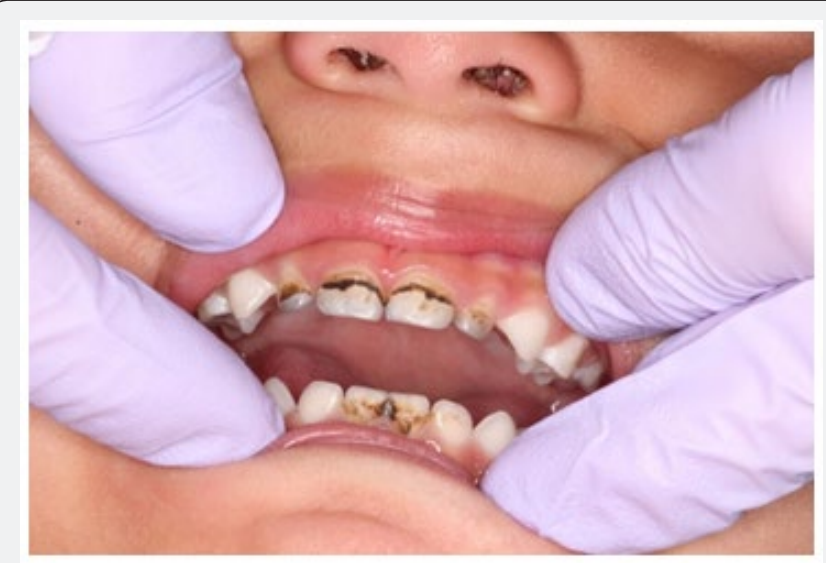

Figure 1: Discolored Caries.

Earlier studies, mostly in countries that have been using this solution for decades have shown that arrest of caries penetrates 50 microns into the affected dentin causing a layer of dead bacteria that will affect newer bacterial invasions by causing their death. The introduction of SDF was initially intended as a root desensitization therapy and further use has resulted in the discovery that it will arrest the decay process with two applications within a year. The time varies with the interval of application but studies have shown it to be more effective when applied twice. The application process is done with caution because the liquid will stain clothes, floors, counters, mucous membrane (temporarily) and hands. When applied in the mouth, it requires some application of Vaseline to the soft tissue to prevent the staining of soft tissue, gloves to protect your own hands and covers for the patients to prevent the ruin of clothing. The teeth are isolated (only five teeth) per daily application and the micro brush loaded with a single drop. Once applied the material can taste metallic, have an unpleasant aroma and needs to be dry for one minute, avoiding dilution by abstinence of food for the next 30 minutes. Then, about two weeks

later, a second application under the same circumstances will permit the appropriate effect.

This works well for small children that might require treatment of multiple caries in the hospital OR. If waiting for OR availability is needed, then this application would allow delay for that individual. What is not known presently is how long the reapplication process can be used prior to definitive care for the patient. Studies that address that issue will have to be conducted to determine that protocol.

How does it work? It appears that the silver component interferes with cathepsins that degrade collegen in the dentin breakdown process and stops bacterial action. Once applied twice, it is expected to last for a couple of years before needing reapplication. Research is necessary to determine the length of effectiveness of this protocol. Will this discolored dentin be able to be restored with the bonding technique needed for tooth colored fillings? Initial results of studies show that bonding of the fillings will not be affected, and thus the restoration can be placed. The outcome of small infant application is that fewer children should be stable until they are older, for final restorations.

If you do not know of this technique, please contact your dentist to see how your child may benefit from this new therapy. 
Be on the lookout for new research in this area. The liquid is available in the U.S. and most offices should be able to apply it or refer you to someone that can.

\section{References}

1. Mei ML, Ito OL, Cao Y, Li QL, Chu CH, et al. (2013) The Inhibitory Effects of Silver Diamine Fluorides on Cysteine Cathepsins. J Dent 42(3): 329 335 .

2. Mei ML, Li Q, Chu CH, Lo ECM, Samaranayake LP (2013) Antibacterial Effects of Silver Diamine Fluoride on Multi-Species Cariogenic Biofilm on Caries. Ann Clin Microbiol Antimicrob 12: 14.

3. Jeremy A Horst, Hellene Ellenikiotis, Peter M Milgrom (2016) UCSF Protocol for Caries Arrest Using Silver Diamine Fluoride: Rationale, Indications and Consent. J Calif Dent Assoc 44(1): 16-28.
4. Chu CH, Lo ECM, Lin HC (2002) Effectiveness of Silver Diamine Fluoride and Sodium Fluoride Varnish in Arresting Dentin Caries in Chinese Preschool Children J Dent Res 81(11): 767-770.

5. Rosenblatt A, Stamford TC, Niedermann R (2009) Silver diamine fluoride: a caries "silver-fluoride bullet". J Dent Res 88(2): 116-125.

6. Koizumi H, Hamama HH, Burrow MF (2016) Effect of a silver diamine fluoride and potassium iodide-based desensitizing and cavity cleaning agent have on bond strength to dentine. International Journal of Adhesion and Adhesives 68: 54-61.

7. Hamama HH, Yiu CK, Burrow MF (2015) Effect of silver diamine and potassium iodide on residual bacteria in dentinal tubules. Aust Dent J 60(1): 80-87.

8. Nelson T, Scott JM, Crystal YO, Berg JH, Milgrom P (2016) Silver Diamine Fluoride in Pediatric Dentistry Training Programs: Survey of Graduate Program Directors. Pediatr Dent 38(3): 212-217.

\section{Your next submission with Juniper Publishers will reach you the below assets}

- Quality Editorial service

- Swift Peer Review

- Reprints availability

- E-prints Service

- Manuscript Podcast for convenient understanding

- Global attainment for your research

- Manuscript accessibility in different formats

( Pdf, E-pub, Full Text, Audio)

- Unceasing customer service

Track the below URL for one-step submission https://juniperpublishers.com/online-submission.php 